\title{
Development Indices of Gongronema latifolium Benth Domesticated in Otuoke Terrestrial Habitat, Bayelsa State, Nigeria
}

\author{
Etukudo, Mbosowo M., (PhD) \\ Department of Biological Sciences, \\ Federal University Otuoke, Yenagoa, Bayelsa State, Nigeria \\ Osim, Samuel E. (PhD) \\ Department of Biological Sciences, \\ Cross River University of Technology, Calabar, Nigeria
}

Doi: 10.19044/esj.2018.v14n24p1 URL:http://dx.doi.org/10.19044/esj.2018.v14n24p1

\begin{abstract}
The effects of physico-chemical properties of two soil sampling locations on the proximate and mineral nutrients contents of Gongronema latifolium Benth were examined in Otuoke secondary forest habitat, in Bayelsa State, Nigeria. Leaf samples of Gongronema latifolium and soil $(0-20 \mathrm{~cm}$ depth) samples were randomly collected from two sites in the study area. Three replicates were maintained for each treatment using randomized complete block design. The $\mathrm{pH}$ of 5.10 was recorded at location 1 while that of location 2 was 5.00. The contents of calcium, magnesium, sodium, phosphorus, iron, copper and zinc were higher in leaves of G. latifolium at location 1 than those of location 2, while the content of potassium was higher in leaves of G. latifolium at location 2 than those of location 1 . The moisture, protein, lipid and fibre contents in leaves of $G$. latifolium were higher at location 1 than those of location 2, while the contents of ash and carbohydrate in leaves of $G$. latifolium were higher at location 2 than those of location 1. This study showed that the nutritional status of $G$. latifolium was affected by the sampling locations of the study area, hence, appropriate cultural practices are needed in the area in order to create favourable soil conditions for optimum growth and development of the test plant.
\end{abstract}

Keywords: Development, Gongronema latifolium, Otuoke

\section{Introduction}

The tropical rainforest in Nigeria is the habitat wide biodiversity of plants and animals. Plants growing in various habitats are influenced by soil, atmospheric and climatic factors (Osuagwu et al., 2013, Etukudo et al., 2015). 
Temporal variations in soil physico-chemical properties such as $\mathrm{pH}$, moisture, total organic matter and total nitrogen availability have been reported to influence living organisms (Bhattacharyya and Jha, 2011; Das and Dkhar, 2011). Soil is a medium for plant growth, thus its composition has a significant influence on the growth and development of plants (Agbede, 2009), The variation in soil components such as organic matter, microbial populations, relative amount of pore spaces and mineral nutrients among different soil types have been reported to influence plant growth and development (Brady and Weil, 2004). Even a small proportion of organic matter are known to have a noticeable effect on the physical, chemical, and biological properties of soil (Brady and Weil, 2004, Agbede, 2009), with a corresponding on plant growth.

Research on medicinal plants has increased in recent times due to the importance attached to human well being. Gongronema latifolium Benth (Asclepiadaceae) is regarded as a non-wood forest product of West African origin (Agbo and Omaliko, 2006). It has been utilized over the years in ethnomedicine for treatment of various ailments and diseases (Eleyinmi, 2007). It leaf extracts are used in the treatment of malaria, diabetes, and hypertension (Edet et al., 2011). It is regarded as one the species that is highly cherished by the local people due to it medicinal values. Its leaf extracts have been reported to exhibit significant effects in inhibition of arthritis formation (Morebise and Fafunso, 1998). In Nigeria, the plant is utilized various medicinal and nutritional purposes (Ugochukwu et al., 2003).

The study area, Otuoke, is a tropical climatic region with characteristic ecological problems resulting from irregular marshy terrains, and seasonal flooding, in addition to the general petroleum oil exploration activities in the Niger Delta region. This study becomes increasingly important because it takes into account the relationship between two soil conditions and development indices of $G$. latifolium in the study area.

\section{Materials and Methods:}

Study area: This study was carried out in otuoke secondary forest habitat, Ogbia, Bayelsa State, Nigeria. Ogbia is located at coordinates of $4^{\circ} 47^{\prime} \mathrm{n}$ and $6^{\circ} 20^{\prime} \mathrm{E}$, and Bayelsa state lies in the heaviest rainfall area of Nigeria with a mean minimum monthly temperature ranging from $25^{\circ} \mathrm{C}$ to $31^{\circ} \mathrm{C}$ (Niger Delta Source, 2014).

\section{Collection of Samples}

Plant (leaves of Gongronema latifolium) and soil (0-20 $\mathrm{cm}$ depth) samples were randomly collected from two sites in the study area. Three replicates were maintained for each treatment using randomized complete block design. 
Analysis of Soil Samples: Chemical properties of soil samples were analysed using standard procedures (A.O.A.C, 2003).

\section{Analysis of Nutrient element}

The plant samples of G. latifolium were dried after rinsing thoroughly with distilled water. The plant materials were crushed into powdered form followed by sieving through a $0.001 \mathrm{~mm}$ wire mesh to obtain a fine powdered form. The samples were placed in small bottles for analysis. Ammoniumvanadate-molybdate method was used to determine phosphorus content by spectrophotometry. Potassium was determined by frame photometer, while other elements were assayed by atomic absorption spectrophotometer (A.O. A.C, 2003, Hack, 2000).

\section{Proximate Analysis}

Proximate values of the plant material were determined using standard procedure (A.O.A.C, 2003, Hack, 2000).

\section{Statistical Analysis}

The data generated from this study were evaluated using Analysis of variance (ANOVA) and differences in the means were tested using Least Significant Differences (LSD) at probability level of 5\% (Ogbeibu, 2005).

\section{Results:}

The physical and chemical properties of the study area are presented in Table 1. The contents of sand, organic carbon, nitrogen, phosphorus, calcium, magnesium, sodium and potassium were higher at location 1 than location 2, while the contents of clay, silt and aluminium were higher at location 2 than location 1 (Table 1 ). The $\mathrm{pH}$ of 5.10 was recorded at location 1 while that of location 2 was 5.00 (Table 1). The contents of calcium, magnesium, sodium, phosphorus, iron, copper and zinc were higher in leaves of Gongronema latifolium at location 1 than those of location 2, while the content of potassium was higher in leaves of Gongronema latifolium at location 2 than those of location 1 (Table 2). The moisture, protein, lipid and fibre contents in leaves of $G$. latifolium were higher at location 1 than those of location 2, while the contents of ash and carbohydrate in leaves of $G$. latifolium were higher at location 2 than those of location 1 (Table 3).

Table 1: Soil physical and chemical properties of the study area

\begin{tabular}{lcc}
\hline Parameters & Location 1 & Location 2 \\
\hline Depth $(\mathrm{cm})$ & $0-20$ & $0-20$ \\
Colour & Very dark greyish brown & Yellowish brown \\
Clay $(\mathrm{g} / \mathrm{kg})$ & $39.00 \pm 0.21$ & $47.00 \pm 0.25$ \\
Silt $(\mathrm{g} / \mathrm{kg})$ & $153.00 \pm 0.45$ & $186.00 \pm 0.32$ \\
Sand $(\mathrm{g} / \mathrm{kg})$ & $808.00 \pm 0.41$ & $767.00 \pm 0.33$
\end{tabular}




\begin{tabular}{lcc}
$\mathrm{pH}$ & $5.10 \pm 0.74$ & $5.00 \pm 0.87$ \\
Org. C $(\%)$ & $1.95 \pm 0.34$ & $1.44 \pm 0.21$ \\
$\mathrm{~N}(\%)$ & $0.13 \pm 0.02$ & $0.12 \pm 0.05$ \\
$\mathrm{P}(\mathrm{mg} / \mathrm{kg})$ & $9.09 \pm 0.54$ & $5.16 \pm 0.43$ \\
$\mathrm{Ca}(\mathrm{c} \mathrm{mol} / \mathrm{kg})$ & $3.60 \pm 0.67$ & $2.24 \pm 0.73$ \\
$\mathrm{Mg}(\mathrm{c} \mathrm{mol} / \mathrm{kg})$ & $2.48 \pm 0.31$ & $0.48 \pm 0.75$ \\
$\mathrm{Na}(\mathrm{c} \mathrm{mol} / \mathrm{kg})$ & $0.38 \pm 0.07$ & $0.21 \pm 0.30$ \\
$\mathrm{~K}(\mathrm{c} \mathrm{mol} / \mathrm{kg})$ & $2.05 \pm 0.22$ & $1.46 \pm 0.18$ \\
$\mathrm{Al}(\mathrm{c} \mathrm{mol} / \mathrm{kg})$ & $0.40 \pm 0.06$ & $0.60 \pm 0.09$ \\
\hline
\end{tabular}

Mean \pm standard error from three replicates

Table 2: Mineral nutrients in leaves of Gongronema latifolium Benth in the study area

\begin{tabular}{lcc}
\hline Mineral nutrients & Location 1 & Location 2 \\
\hline $\mathrm{Ca}(\mathrm{mg} / 100 \mathrm{~g})$ & $20.21 \pm 0.22$ & $18.43 \pm 0.30$ \\
$\mathrm{Mg}(\mathrm{mg} / 100 \mathrm{~g})$ & $7.65 \pm 0.45$ & $6.17 \pm 0.28$ \\
$\mathrm{Na}(\mathrm{mg} / 100 \mathrm{~g})$ & $11.12 \pm 0.54$ & $10.21 \pm 0.42$ \\
$\mathrm{~K}(\mathrm{mg} / 100 \mathrm{~g})$ & $13.61 \pm 0.33$ & $15.26 \pm 0.93$ \\
$\mathrm{P}(\mathrm{mg} / 100 \mathrm{~g})$ & $0.69 \pm 0.04$ & $0.62 \pm 0.02$ \\
$\mathrm{Fe}(\mathrm{mg} / 100 \mathrm{~g})$ & $0.46 \pm 0.07$ & $0.42 \pm 0.06$ \\
$\mathrm{Mn}(\mathrm{mg} / 100 \mathrm{~g})$ & $0.34 \pm 0.04$ & $0.37 \pm 0.03$ \\
$\mathrm{Cu}(\mathrm{mg} / 100 \mathrm{~g})$ & $0.17 \pm 0.02$ & $0.15 \pm 0.04$ \\
$\mathrm{Zn}(\mathrm{mg} / 100 \mathrm{~g})$ & $0.43 \pm 0.05$ & $0.42 \pm 0.09$ \\
\hline
\end{tabular}

Mean \pm standard error from three replicates

Table 3: Proximate contents in leaves of Gongronema latifolium Benth in the study area

\begin{tabular}{lcc}
\hline \multicolumn{2}{l}{ Proximate contents Location 1 } & \multicolumn{2}{c}{ Location 2} \\
\hline Moisture (\%) & $3.09 \pm 0.27$ & $2.90 \pm 0.34$ \\
Ash (\%) & $0.74 \pm 0.03$ & $0.82 \pm 0.08$ \\
Protein (\%) & $8.30 \pm 0.42$ & $7.26 \pm 0.18$ \\
Lipids (\%) & $1.56 \pm 0.72$ & $1.43 \pm 0.30$ \\
Fibre (\%) & $2.66 \pm 0.81$ & $2.49 \pm 0.48$ \\
Carbohydrate (\%) & $86.74 \pm 0.56$ & $88.02 \pm 0.23$ \\
\hline \multicolumn{3}{c}{ Mean \pm standard error from three replicates }
\end{tabular}

\section{Discussion}

In this study, significant variations existed in the soil physical and chemical properties between the two locations. This variations may be due to differences in both cultural and ecological conditions in the two sampling locations. Soil characteristics have been reported to be influenced by cultural practices (Agbede, 2009, Maynard and Hochonuth, 2007). Soil physical characteristics such as pore space are known to be influenced by soil texture and soil management (Crouse, 2017). In addition, parent material can vary based on soil location, while the general properties of soil may vary with depth (Crouse, 2017, Agbede, 2009). Differences in even one of the factors that influence soil formation such as parent material, biological activity, climate, topography and time can result in a different soil type (Brady and Weil, 2007, Dune, 2007). 
The soil physical and chemical characteristics of the sampling locations also affected the mineral nutrients and the proximate contents in leaves of $G$. latifolium. This result is in line with the work Ohshiro et al. (2016) that the contents of elements such as $\mathrm{Na}, \mathrm{K}$, and $\mathrm{Ca}$ in amaranth plants were higher when cultivated in soils with higher levels of available minerals$\mathrm{Na}, \mathrm{K}$ and $\mathrm{Ca}$. Nutrient availability, absorption, and plant growth differ significantly with the physical, chemical, and biological factors of soil (Donald and Katherine, 1999). Similarly, the proportion of sand, silt and clay which depict the textural status of soil also affect nutrient absorption and plant growth (Hossain and Ishimine, 2005, Agbede, 2009).

\section{Conclusion:}

This study showed that the nutritional status of $G$. latifolium was affected by the sampling locations. The soil is a medium for plant growth, hence, its physical and chemical properties affect the nutrient availability, absorption as well as plant growth and development.

\section{References:}

1. Agbede, O.O. (2009). Understanding soil and plant nutrition. Nigeria, Salmon Press and Co. Ltd.

2. Agbo, C. U.\& Obi, I. U. (2006). Macro-propagation technique for different physiologyical ages of Gongronema latifolia Benth cuttings. African Journal of Biotechnology, 5(13): 1254-1258

3. A.O.AC., (2003). Association of Official Analytical Chemist. Methods of analysis, Washington DC., U.S.A.

4. Bhattacharyya, P. N, \&Jha, D. K. (2011). Seasonal and depth wise variation in microfungal population numbers in Nameri forest soil, Assam, northeast India. Mycosphere, 2(4): 297-305.

5. Brady, N. C., \& Weil, R. R. (2007). The Nature and Properties of Soils. $14^{\text {th }}$ ed. Upper Saddle River, New Jersey: Prentice Hall, Inc.

6. Crouse, D. A. (2017). Soils and Plant Nutrients, Chpt. 1. In: In: K.A. Moore, and. L.K. Bradley (eds). North Carolina Extension Gardener Handnook. NC State Extension, Raleigh, NC.

7. Das, B. B. \& Dkhar, M.S. (2011). Rhizosphere microbial populations and phisico chemical properties as affected by organic and inorganic farming practices. Am. Eur. J. Agric. Environ. Sci. 10(2):140-150.

8. Donald, L. A., \& Katherine, P. G. (1999). Better crops with plant food. Better Crops, 83: 1-39.

9. Dunne, N. (2009). Healthy Soils for Sustainable Gardens. Dunne, Niall, ed. Brooklyn, New York: Brooklyn Botanic Garden,

10. Edet, E. E., Akpanabiatu, M. I., Uboh, F. E. Edet, T. E., Eno, A. E. Itam, E. H.\& Umoh, I. B. (2011). Gongronema latifolium Crude Leaf 
Extract Reverses Alterations in Haematological Indices and Weightloss in Diabetic Rats. Journal of Pharmacology and Toxicology, 6: 174-181.

11. Eleyinmi, A. F. (2007). Chemical composition and bacterial activity of Gongronema latifolium. Journ. Zhejiang Univ. Sci. B. 8(5): 352-358

12. Etukudo, M. M., Hamilton-Amachree, A., \& Roberts, E. M. I. (2015). Eco-physiological Studies of Elemental and Proximate Contents of Gnetum africanum Welw and Telfairia occidentalis Hook seeds from two Ecological Zones of Akwa Ibom State. European International Journal of Science and Technology. 4(6):4753.

13. Hack, B. (2000). Analytical method of determination of mineral nutrients. In: Dolphin and John, S (eds.). Text on analytical in practice, Incorp. Press Ltd. New York.

14. Hossain, M. A., \& Ishimine, Y. (2005). Growth, yield and quality of turmeric (Curcuma longa L.) cultivated on dark-red soil, gray soil and red soil in Okinawa, Japan. Plant Production Science, 8, 482-486.

15. Maynard, D. N. \& Hochmuth, G. J. (2007). Knott's Handbook for Vegetable Growers. $5^{\text {th }}$ ed. Hoboken, New Jersey: John Wiley \& Sons, Inc.

16. Morebise, O. \& Fafunso, M. A. (1998). Antimicrobial and phytotoxic activities of saponin extracts from two Nigerian edible medicinal plants. Biokemistri. 8(2):69-77.

17. Niger Delta Source: Bayelsa State. (2014). http://nigeriadeltasource.com/bayelsa

18. Ogbeibu, A.E. (2005). Biostatistics: A practical approach to research and data handling. Mindex Publishing Company Limited, Benin.

19. Ohshiro, M., Hossain, M. A., Wakamara, I., Akamine, H., Tamak, M., Bhownuk, P. C. \& Nox, A. (2016). Effects of soil types and fertilizers on growth, yield, and quality of edible Amaranthus tricolor lines in Okinawa, Japan. Plant Production Science, 19 (1): 61-72.

20. Osuagwu, A. N., Ekpo, I. A., Okpako, E. C, Out, P. \& Ottoho, E. (2013). The Biology, Utilization and Phytochemical Composition of the fruits and leaves of Gongronema latifolium Benth. Agrotechnol. 2:115.

21. Ugochukwu, N, H., Babady, N. E., Cobourne, M.K. \& Gasset, S. R. (2003). The Effect of Gongronema latifolium Extracts on Serum Lipid Profile and Oxidative Stress in Hepatocytes of Diabetic Rats. Journ. Biosci. 28(1):1-5. 